\title{
INVESTIGATION OF THE SANITARY STATE OF AIR AND REFRIGERATION EQUIPMENT OF MEAT PROCESSING ENTERPRISES IN KAZAKHSTAN USING THE METHOD OF METAGENOMIC ANALYSIS
}

\author{
Lazat Umiralieva ${ }^{1}$, Anna Chizhayeva², Akniyet Ibraikhan, \\ Cholponkul Avylov³, Masimzhan Velyamov ${ }^{1}$ \\ ${ }^{1}$ Kazakh Research Institute of Processing and Food Industry LLP, 238 “G” Gagarin Ave, Almaty, 050060, Republic \\ of Kazakhstan \\ ${ }^{2}$ SPC of Microbiology and Virology, 103 Bogenbai Batyr str., Almaty, 050010, Republic of Kazakhstan \\ ${ }^{3}$ FSBEI HE Moscow State University of Food Production, 11 Volokolamsk Highway, Moscow, 125080, Russia
}

Link to this article: https://doi.org/10.11118/actaun.2021.037

Received: 23. 3. 2021, Accepted: 17. 5. 2021

To cite this article: UMIRALIEVA LAZAT, CHIZHAYEVA ANNA, IBRAIKHAN AKNIYET, AVYLOV CHOLPONKUL, VELYAMOV MASIMZHAN. 2021. Investigation of the Sanitary State of Air and Refrigeration Equipment of Meat Processing Enterprises in Kazakhstan Using the Method of Metagenomic Analysis. Acta Universitatis Agriculturae et Silviculturae Mendelianae Brunensis, 69(3): 403-416.

\begin{abstract}
Taking into account the appearance of "new pathogens", persistent and uncultivated microorganisms, increasing the resistance of modern strains of microorganisms to disinfectants, increasing their antibiotic resistance and ability to biofilm formation, there is a need to study the microbial community of refrigerating chambers at meat processing enterprises in modern conditions, which was the aim of this work. The study of sanitary condition of the refrigeration equipment of a meat processing plants of the Almaty region of Kazakhstan was carried out by classical methods of microbiology and metagenomic analysis. Methods of classical microbiology allowed to identify the following microflora of refrigerating chambers of meat processing enterprises: bacteria Bacillus subtilis, Bacillus mesentericus, Pseudomonas sp., Sarcina flava, yeast Rhodotorula sp., mycelial fungi Penicillium sp., Alternaria sp., Mucor sp., Aspergillus sp., Chrososporum sp., Tamnidium sp. Metagenomic analysis showed that the bacterial microflora of refrigerating chambers is mainly represented by three phyla: Firmicutes (95.33\%-97.94\%), Proteobacteria (1.39\%-1.02\%), Actinobacteria (1.11\%-0.63\%) and their ratio depends on the temperature of the refrigerators well as on the observance of hygiene standards by personnel. The research results can serve as the basis for recommendations for improving the sanitary condition and safety at meat processing plants.
\end{abstract}

Keywords: refrigerating chambers, microbial contamination, meat, meat products, bacteria, yeast, mold, metagenomic analysis

\section{INTRODUCTION}

Meat and meat products are among the most important food products, as they are the main source of complete proteins of animal origin. Recent data indicate that meat consumption is steadily increasing worldwide and reached $34 \mathrm{~kg}$ per capita in 2019 (beef and veal - 6.4; poultry - 14.7; pork - 11.1; lamb
- 1.8). The same trend of increasing consumption is observed in Kazakhstan, the most consumed type of meat here is beef and veal - 19.7 kilograms per capita; then poultry meat - 16.5 kilograms per capita; lamb - 8.2 kilograms per capita; pork - 4.7 kilograms per capita. Meat consumption growth over the next decade is projected to increase by another $12 \%$ by 2029 (OECD, 2020; OECD/FAO, 2020). 
In connection with growth of consumption and production of meat and meat products, an important issue is to ensure microbial safety the absence of pathogens or toxic metabolites, no harm to human health in terms of infectious diseases. However, in recent years, a large number of claims for meat and meat products are related to microbiological problems (Pal et al., 2018). The main sources of microbiological contamination of food products and food raw materials are the environment, raw materials, technological process, personnel. The occurrence of contamination is possible at all stages of processing of animal raw materials, as well as during storage, transportation and sale of the finished food product. At the same time, violation of sanitary and hygienic standards of these processes can lead to a sharp increase in the number of microorganisms compared to their initial content. Raw meat and meat products as a result of infection with pathogenic, toxigenic and saprophytic microorganisms can pose a direct danger to human health, causing food poisoning and diseases of varying severity. Despite the wellbeing of the situation with the main zoonoses and the improvement of production conditions, in recent years, there has been an increase in acute intestinal and other infectious diseases transmitted by food. According to FAO/WHO nearly 600 million people fall ill and 420,000 die each year as a result of food-borne diseases, resulting in the loss of 33 million years of healthy life. Low-and middleincome countries are the most affected, with losses from reduced productivity, trade-related damage, and the cost of treating diseases caused by unsafe food consumption estimated at $\$ 110$ billion annually (FAO, 2019).

Obviously, this was a consequence of the general biological phenomenon of the evolution of microorganisms and the appearance among them of so-called "new pathogens" with altered properties and behavior. The formation of new pathogens has accelerated as a result of anthropogenic and man-made impacts on the environment and the organisms inhabiting it. The use of antibiotics in livestock breeding, intensive technologies for fattening livestock and poultry in confined spaces have triggered the mechanism of gene mutations and selective selection of antibioticresistant microorganisms, primarily from among the representatives of the microflora of the gastrointestinal tract of animals ( $E$. coli, bacteria of the genera Salmonella, Enterococcus). As a rule, they are more resistant in the environment and food, have increased aggressiveness and lower infecting doses.

In addition to food pathogens, meat spoilage can be caused by other microorganisms, the growth and metabolic activity of which during the shelf life lead to changes in color, smell, taste or texture defects (Wickramasinghe et al., 2019; Pennacchia et al., 2011; Doulgeraki et al., 2012) and, consequently, to large economic losses in the meat processing sector.
Since meat and meat products are among the perishable food products, their long-term storage under normal conditions is impossible without special processing. At present, along with various methods of preserving perishable food products, refrigeration processing of meat and its storage at appropriate low temperatures are one of the most advanced methods of preventing or slowing down the spoilage of this product (Ercolini et al., 2006; Olusegun and Iniobong, 2011; Rouger et al., 2017; Sauter, 1987; Nieminen, Koskinen et al., 2012; Nieminen, Valitalo et al., 2012; Coombs et al., 2017).

Cold treatment suppresses the vital activity of microorganisms, as well as slows down the chemical and biochemical processes that occur in the product under the influence of its own enzymes, air oxygen, heat and light (Sokolov and Sokolov, 2015).

The nature and depth of changes during cooling and subsequent storage of meat depend on the type and quality of raw materials, but not to a lesser extent on the conditions, modes and hygiene of refrigerated processing (Kostenko, 2015; Tulyakova et al., 2013). It should be noted that, at present, technologies of cold storage and sealed packaging have created conditions conducive to the manifestation of poorly studied psychrotrophic and microaerophilic microorganisms, which were not previously associated with "food" diseases. Along with the evolution of pathogens, there is an evolution of the ways of their spread, new ecological niches and habitats appear.

Environmental stress, in particular low temperature, leads to changes in metabolic processes in cells and, at the initial stages, to the formation of persistent cells (Mei et al., 2016). With prolonged stress, an increase in free toxins, metabolic activity decreases even more strongly, cells remain viable, but not cultured (viable but non-cultured-VBNC cell). These groups of microbial cells cannot be detected by classical microbiological methods with identification on selective nutrient media. However, they can affect the circulation of pathogens in the meat processing industry, reduce the shelf life, quality and safety of meat and meat products, also they can cause infection of consumers with salmonellosis, listeriosis, campylobacteriosis (Brooks and Flint, 2008). Reason for the persistence of food poisoning pathogens in processing plants is their ability to form biofilms (Bai and Rai Vittal, 2014; Lee et al., 2014; Liu et al., 2018; Liu et al., 2015).

Microbiological control, including the use of modern metagenomic technologies, allows timely detection of the degree of contamination of refrigerating chambers with molds and pathogenic bacteria, as such, the appropriate measures can be taken (Delhalle et al., 2020; Rouger et al., 2017; Mohareb et al., 2015; Stanborough et al., 2018; Stellato et al., 2016). In this regard, research in the direction of studying the sanitary and hygienic condition of refrigerators, refrigerating chambers and air, taking into account all groups 
of microorganisms, to ensure the safety of storage and turnover of meat and meat products is very relevant.

\section{MATERIALS AND METHODS}

\section{Sampling and Their Study by the Classical Microbiological Method}

Sampling was carried out at meat processing plants of the Almaty region (southeast of Kazakhstan). Objects of research: air and surfaces of walls, hooks, shelves of refrigerating chambers; isolated microorganisms; cooled beef meat (cuts, small-sized meat); meat products - boiled sausage, smoked sausage. The determination of microbial contamination of cold rooms with bacteria, yeast and molds was carried out in two refrigerating chambers (Tab. I).

Samples to determine the contamination of the walls and air were taken at a time when no loading and unloading operations were carried out in the chambers. The walls of refrigerating chambers of meat processing plants are covered with painted metal panels, washing and disinfection of the chambers is carried out before loading and after unloading the chambers with meat. After carrying out of sanitation (des. Product-Kalgonite CF 310, Russia) at the meat processing enterprise, we carried out visual, chemical and microbiological quality control of the work performed. Then, after loading the chambers with meat, on the $3^{\text {rd }}$, $5^{\text {th }}$ and $7^{\text {th }}$ days, microbiological control of the sanitary condition of the walls, shelves, hooks and inventory, as well as analysis of the air of the chambers, was carried out.

The study of quantitative microbial contamination of surfaces and air in refrigerating chambers of meat processing plants of Almaty region was carried out with the help of two-factor planning under the program Statgraphics Centurion XVI (DOE-Experimental Design Wizard unit). The most important factors were chosen as variables based on the results of microbiological studies: chamber temperature $x_{1}\left({ }^{\circ} \mathrm{C}\right)$, storage time of meat samples and meat products $x_{2}$ (sampling days). The number of microorganisms $\left(\mathrm{CFU} / \mathrm{cm}^{2}\right)$ on the walls of the refrigerating chambers $y_{1}$, on the shelves and hanging hooks of the refrigerating chambers $y_{2}$ and in the air of the refrigerating chambers $y_{3}$ was selected as the output parameter, the average values of which are given in Tab. II.

In parallel with these studies, meat samples were taken to analyze its sanitary condition and safety. The tests were carried out once a month during the winter, spring and summer seasons.

Microbiological study of the contamination of the walls of the refrigerating chambers was carried out by washing out. A sterile solution of $8.5 \mathrm{~g} \mathrm{NaCl}, 1 \mathrm{~g}$ trypton casein-peptone, $0.1 \mathrm{~g}$ agar, and distilled water up to $100 \mathrm{ml}$ (protocol, HACCP) was used to moisten cotton swabs to select flushes and obtain dilutions (UK Statutory Instruments, 2002). Washouts for control and determination of microbial contamination $\left(\mathrm{CFU} / \mathrm{cm}^{2}\right)$ of refrigeration equipment were taken with a sterile sponge soaked in a sterile flushing solution from a surface of $25 \mathrm{~cm}^{2}$ according to the accepted method. Washouts were taken from four walls of the chamber, so the sample for analysis was flushed from an area of $100 \mathrm{~cm}^{2}$. Washouts from large equipment and inventory were also taken from a surface area of $100 \mathrm{~cm}^{2}$; washouts from small equipment and inventory were taken from the entire surface; washouts from shelves or equipment with a complex configuration were made from different surfaces separately.

After wiping the restricted area, the sponge was placed in a sterile plastic tube, and the samples were delivered to the laboratory in a cooler bag with ice. Then $10 \mathrm{ml}$ of sterile normal saline solution was added to the flask. They were kept for 10 minutes, then vigorously stirred for $1 \mathrm{~min}$ on a vortex and sown in three sterile Petri dishes of $1 \mathrm{ml}$ of suspension, filled with molten and cooled to $42-45^{\circ} \mathrm{C}$ with a nutrient medium. We used standardized nutrient media, according to the protocol recommended by HACCP (UK Statutory Instruments, 2002) for monitoring the sanitary and

I: Characteristics of operation modes of refrigerating chambers (according to refrigerators control panel readings) and their storage objects

\begin{tabular}{|c|c|c|}
\hline Modes and storage objects & Refrigerator No. 1 & Refrigerator No. 2 \\
\hline Air temperature & $-4.5^{\circ} \mathrm{C}$ & $+4.5^{\circ} \mathrm{C}$ \\
\hline Relative air humidity & $90 \pm 2 \%$ & $82 \% \pm 2 \%$ \\
\hline Speed of air movement & $0.2 \mathrm{~m} / \mathrm{s}$ & $0.1-0.2 \mathrm{~m} / \mathrm{s}$ \\
\hline The loading rate & 70\% at camera capacity & $20 \%$ at camera capacity \\
\hline Objects of storage & Beef in cuts and byproducts & Meat products (sausages) \\
\hline $\begin{array}{l}\text { Conditions for storing beef } \\
\text { and meat products }\end{array}$ & $\begin{array}{l}\text { Pieces of meat lay on metal shelves } \\
\text { and not contacting each other; byproducts } \\
\text { were in metal boxes with lids. }\end{array}$ & $\begin{array}{l}\text { Sausages were hung on metal shelves } \\
\text { and not contacting each other }\end{array}$ \\
\hline The storage duration & 7 days & 7 days \\
\hline
\end{tabular}


hygienic state of production: wort agar (Wort agar), MPA, Chapek medium, Saburo medium, trypton yeast extract - glucose medium (HiMedia, India), which allow us to distinguish different taxonomic groups of microorganisms. The inoculations were kept for seven days at a temperature of $25 \pm 2{ }^{\circ} \mathrm{C}$ to count mesophilic microorganisms, and at $+4,+6{ }^{\circ} \mathrm{C}$ to record the psychrophilic microorganisms.

Determination of mold content in the air of refrigerating chambers was carried out by the method of settling of microorganisms and their spores on the surface of a dense nutrient medium in Petri dishes. Five sterile dishes, previously filled with molten and cooled to $42-45^{\circ} \mathrm{C}$ wort agar mixed with meat-peptone agar (CA + MPA, 1:1) or other nutrient medium (HACCP protocol), were placed on the floor on sterile paper, one in each of the four corners and one in the middle of the chamber. The duration of exposure of open dishes is 10 minutes. The cultivation of microorganisms was carried out in the same way as when determining the contamination of walls.

Identification and classical identification of microorganisms was carried out with the study of a complex of signs: the nature of growth on nutrient media, Gram stain, the study of morphological, biochemical parameters, serological signs. Identification of microorganisms is carried out using the "Bergey's manual" (Vos et al., 2009; Krieg et al., 2010; Whitman et al., 2012) and other methodological manuals.

\section{Metagenomic Analysis to Determine Microbial Contamination of Refrigerating Chambers}

Sampling of washouts from the surface of walls and shelves was carried out as in the classical microbiological analysis, but the total area of washouts was increased to $500 \mathrm{~cm}^{2}$. When sampling the air, increasing the number of Petri dishes with a nutrient medium by five times and the exposure time to 15 minutes did not allow to collect a sufficient amount of DNA product. Therefore, in further studies, metagenomic analysis of washouts from the surface of walls, shelves and hooks of refrigerating chambers was used. After sampling, all washout samples were concentrated in the laboratory by ultracentrifugation $(30,000 \mathrm{rpm})$ or membrane filtration. The concentrated samples were then used for DNA isolation and subsequent metagenomic sequencing.

16S metagenomic sequencing (Next generation sequencing) was performed on a genome-wide $2^{\text {nd }}$ generation MiSeq sequencer (Illumina, USA). DNA from the samples was isolated directly without the stage of microbiological cultivation using the PureLink ${ }^{\mathrm{TM}}$ Microbiome DNA Purification Kit (Invitrogene, Carlsbad, USA) according to the manufacturer's protocol. The DNA concentration in the samples was determined using a Qubit ${ }^{2} 2.0$ fluorometer using the Qubit ${ }^{\mathrm{TM}}$ dsDNA HS Assay Kit (Life Technologies, Oregon, USA).

Genetic DNA libraries (a collection of fragments of the test DNA sample) for sequencing were prepared according to the $16 \mathrm{~S}$ Metagenomic Sequencing Library Preparation guide (part No. 15044223 rev. A). Variable V3 and V4 regions of the 16S rRNA gene were amplified using universal bacterial primers with the addition of Illumina adapters and certain sequences of nucleotide pairs for the forward primer: 5'-TCGTCGGCAGCGTCAGATGTGTATAAGAGACAGCCTAC GGGNGGWGCAG-3' and for the reverse primer: 5'-GTCTCGTGGGCTCGGAGATGTGTATAAGAGACAGGACTACHVGGGTATCTAATCC-3' (Klindworth et al., 2013). The reaction mixture consisted of: $2.5 \mu$ of DNA matrix; $5 \mu$ l of each primer in $1 \mu \mathrm{m}$ concentration; $12.5 \mu \mathrm{l}$ of KAPA HiFi HotStart readymix in $2 \mathrm{X}$ concentration (KAPA Biosystems, Cape Town, South Africa). PCR amplification was performed in the Eppendorf Mastercycler pros (Eppendorf, Hamburg, Germany) according to the following program: $95^{\circ} \mathrm{C}$ for 3 minutes, followed by 25 amplification cycles of $95^{\circ} \mathrm{C} 30$ seconds, $55^{\circ} \mathrm{C} 30$ seconds, $72{ }^{\circ} \mathrm{C} 30$ seconds and one cycle at $72^{\circ} \mathrm{C}$ for 5 minutes. The PCR product was purified using the Agencourt AMPure PCR purification kit (Beckman Coulter Inc. Beverly, Massachusetts, USA). Illumina indices were added to the resulting PCR product in an additional amplification step. Nextera XT Index primer adapters (Illumina Inc., San Diego, CA, USA) were added to each sample by amplification in a reaction mixture consisting of $12.5 \mu \mathrm{l}$ KAPA HiFi HotStart readymix, $5 \mu \mathrm{l}$ of each index primer, $10 \mu \mathrm{l}$ of water, and $5 \mu \mathrm{l}$ of PCR product. Amplification program: $95^{\circ} \mathrm{C}$ for 3 minutes, then 8 amplification cycles of $95^{\circ} \mathrm{C} 30$ seconds, $55^{\circ} \mathrm{C} 30$ seconds, $72^{\circ} \mathrm{C} 30$ seconds and one cycle at $72^{\circ} \mathrm{C}$ for 5 minutes. The PCR product was purified using the Agencourt AMPure PCR purification kit (Beckman Coulter Inc. Beverly, Massachusetts, USA). At each stage of library preparation, the concentration and size of the PCR product were determined by detection in agarose gel and on the Agilent DNA 1000 Kit bioanalyzer (Agilent Technologies, Germany). The concentration of each sample was adjusted to $4 \mathrm{nM}$ and combined into a single pool. The combined libraries are denatured with $\mathrm{NaOH}$, diluted with hybridization buffer. Next, a common pool of samples was connected to the phix control.

Sequencing was performed on the Illumina MiSeq device (USA) using the MiSeq ${ }^{\circledR R}$ Reagent Kit v3 (600 cycles) (Illumina Inc., San Diego, CA, USA), following the manufacturer's recommendations. The resulting libraries were inserted into the cartridge of the sequencing kit, the cartridge and the flow cell were loaded into the device, and the sequencing program was run on the device.

Data analysis and processing were performed using MiSeq ${ }^{\circledR}$ Reporter Software (Illumina). 
II: Effect of chamber temperature and duration of samples storage on the total number of microorganisms

\begin{tabular}{|c|c|c|c|c|}
\hline$x_{1}$ & $x_{2}$ & $y_{1}$ & $y_{2}$ & $y_{3}$ \\
\hline-4.5 & 5 & $(1.3 \pm 0.07) \times 10$ & $(2.89 \pm 0.7) \times 10^{2}$ & $(0.6 \pm 0.02) \times 10$ \\
\hline & 7 & $(3.2 \pm 0.2) \times 10$ & $(8.23 \pm 1.2) \times 10^{2}$ & $(0.9 \pm 0.03) \times 10$ \\
\hline+4.5 & 5 & $(0.3 \pm 0.02) \times 10$ & $(8.5 \pm 0.5) \times 10$ & $(1.3 \pm 0.02) \times 10$ \\
\hline & 7 & $(0.6 \pm 0.03) \times 10$ & $(1.6 \pm 0.4) \times 10^{2}$ & $(2.5 \pm 0.2) \times 10$ \\
\hline
\end{tabular}

Taxonomic identification was performed by analyzing the V3 and V4 regions of the 16S rRNA gene of bacteria from the International Greengenes database Lawrence Berkeley National Laboratory (USA) at the level: kingdom, phylum, class, order, family, genus and species (The Greengenes Database, 2015).

\section{Sampling of Meat}

Samples were taken, without pre-roasting the surface of the cut, from each part of the meat carcass under study in a whole piece weighing at least $300 \mathrm{~g}$.

Determination of sanitary status of meat and meat products conducted in accredited testing laboratory "Nutritest" LLP, Almaty: defining Quantity of Mesophilic Aerobic and Facultative Anaerobic Microorganisms according to GOST 10444.15-94; CGB (coliforms) according to GOST 31747-2012; determination of pathogenic microorganisms, including Salmonella according to GOST 31659-2012; detection of $L$. monocytogenes according to GOST 32031-2012; determining sulfatereducing bacteria and Staphylococcus aureus according to GOST 9958-81.

The experiments were carried out in threefold repetition. For mathematical processing of the results, standard methods for finding the average values and their average errors were used (Dospekhov, 2012).

\section{RESULTS}

The results of traditional microbiological studies of quantitative microbial contamination of surfaces and air of refrigerating chambers of meat processing enterprises of the Almaty region are presented in Tab. II. During the entire period of the experiment, 864 samples of washouts from the walls, 1080 samples of washouts from shelves and hanging hooks, 1080 samples of air were examined. Tab. II shows the average results of microbiological studies, since there was no days and seasonal difference in the total microbial number $(p<0.05)$.

The dependence of the output parameter on the microbial analysis variables was approximated by regression equations:

$$
\begin{aligned}
y_{1}= & 0.2528+0.1574 x_{1}-0.33 x_{2}+0.4115 x_{1}^{2}- \\
& -0.0611 x_{1} x_{2}+0.0583 x_{2}^{2} \\
y_{2}= & -7.7271+0.4081 x_{1}+3.1483 x_{2}+0.2133 x_{1}^{2}- \\
& -0.1092 x_{1} x_{2}-0.2813 x_{2}^{2}
\end{aligned}
$$$$
y_{3}=-1.25+0.137 x_{1}+0.25 x_{2}+0.0469 x_{1}^{2}+0.44 x_{1} x_{2} .(3)
$$

The regression equations adequately reflect the results of the experiment, since for the number of microorganisms the value $\mathrm{P}<0.05$, there is a statistically significant association between $y$ and factors at a confidence level of 95.0\%. Figs. 1-3 show response intervals illustrating the dependence of the number of microorganisms on variable factors.

According to the data presented in Tab. II, Figs. 1-3 and the requirements of the SanPiN, the studied refrigerating chambers are clean. The degree of microbial content of the walls of refrigerating chambers is quite low, does not exceed the requirements of the standard and is mainly represented by bacterial and yeast microflora, to a lesser extent - mold fungi. The number of wall microorganisms during storage varies slightly.

Microbiological analysis of the sanitary condition of the shelves immediately after washing and disinfection showed that they, unlike the walls, are not cleaned thoroughly enough and can subsequently serve as a source of contamination of the chamber air, meat and meat products stored on them. Immediately after disinfection, single cells of bacteria (Pseudomonas sp.), yeast (Rhodotorula sp.) and mold (Aspergillus sp.) were found in the washouts from the surface of the shelves in the refrigerator for beef cuts and byproducts. Single cells of spore bacteria (Bacillus spp.) were found on the shelves in the refrigerator for meat products (sausages). Single cells of the mold fungus (Penicillium sp.) were found in the washouts from the hooks on the $7^{\text {th }}$ day of storage.

Microbiological analysis of the air, on the contrary, indicates the predominance of mold spores and bacteria in it. They appear in the air on the $3^{\text {rd }}$ and subsequent days of storage of meat and meat products. This may indicate insufficient 


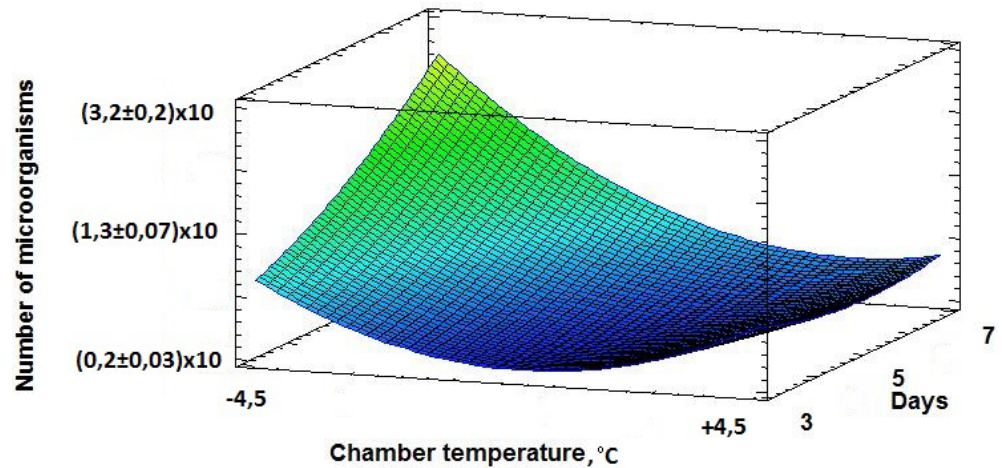

1: Three-dimensional model in space, characterizing the influence of variable factors (chamber temperature and storage duration of meat and clear products) on the number of microorganisms on the walls of refrigerating chambers

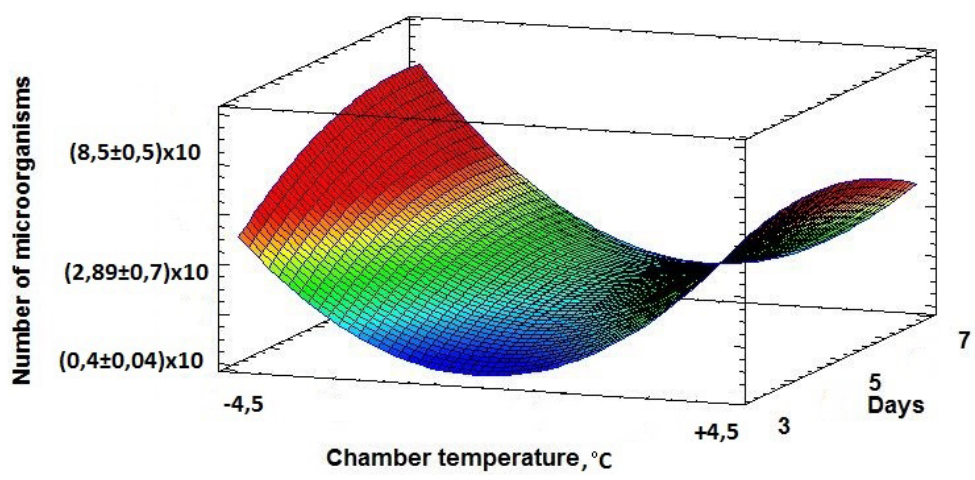

2: Three-dimensional model in space, characterizing the influence of variable factors (chamber temperature and storage duration of meat images and clear products) on the number of microorganisms on shelves and hanging hooks of refrigerating chambers

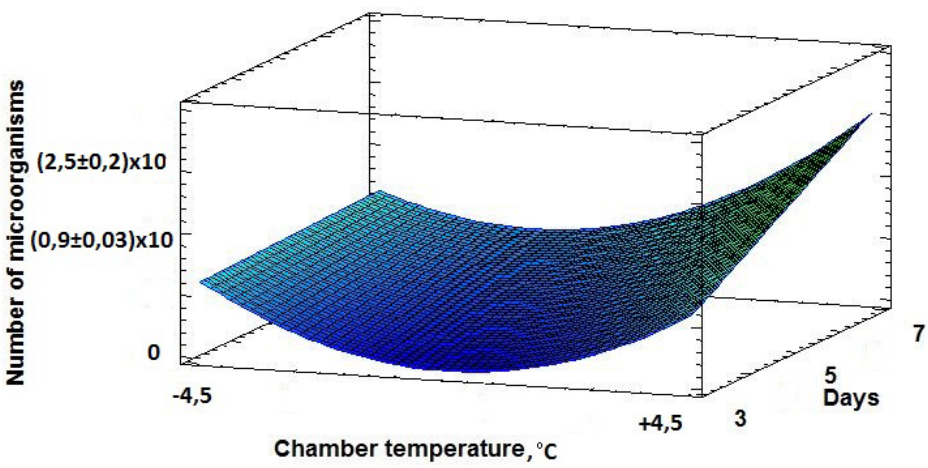

3: Three-dimensional model in space, characterizing the influence of variable factors (chamber temperature and storage duration of meat and meat products images) on the number of microorganisms in the air of refrigerating chambers

compliance with sanitary requirements by personnel, the introduction of foreign microflora and contamination of refrigerators by employees during their stay in the refrigerator, the placement of meat, byproducts and meat products for storage.

The results of the classical identification of eliminated isolates of microorganisms before the genus showed the presence of the following groups of microorganisms:
- In refrigerator No. 1, designed for storing the cooled beef cuts and byproducts, a cells of sporeforming mesophilic bacteria of the genus Bacillus (B. subtilis, B. mesentericus); Pseudomonas sp., Sarcina flava, yeast Rhodotorula sp., mycelial fungi of the genus Penicillium, Alternaria, Mucor, Aspergillus and Chrososporum were detected in the washouts. 


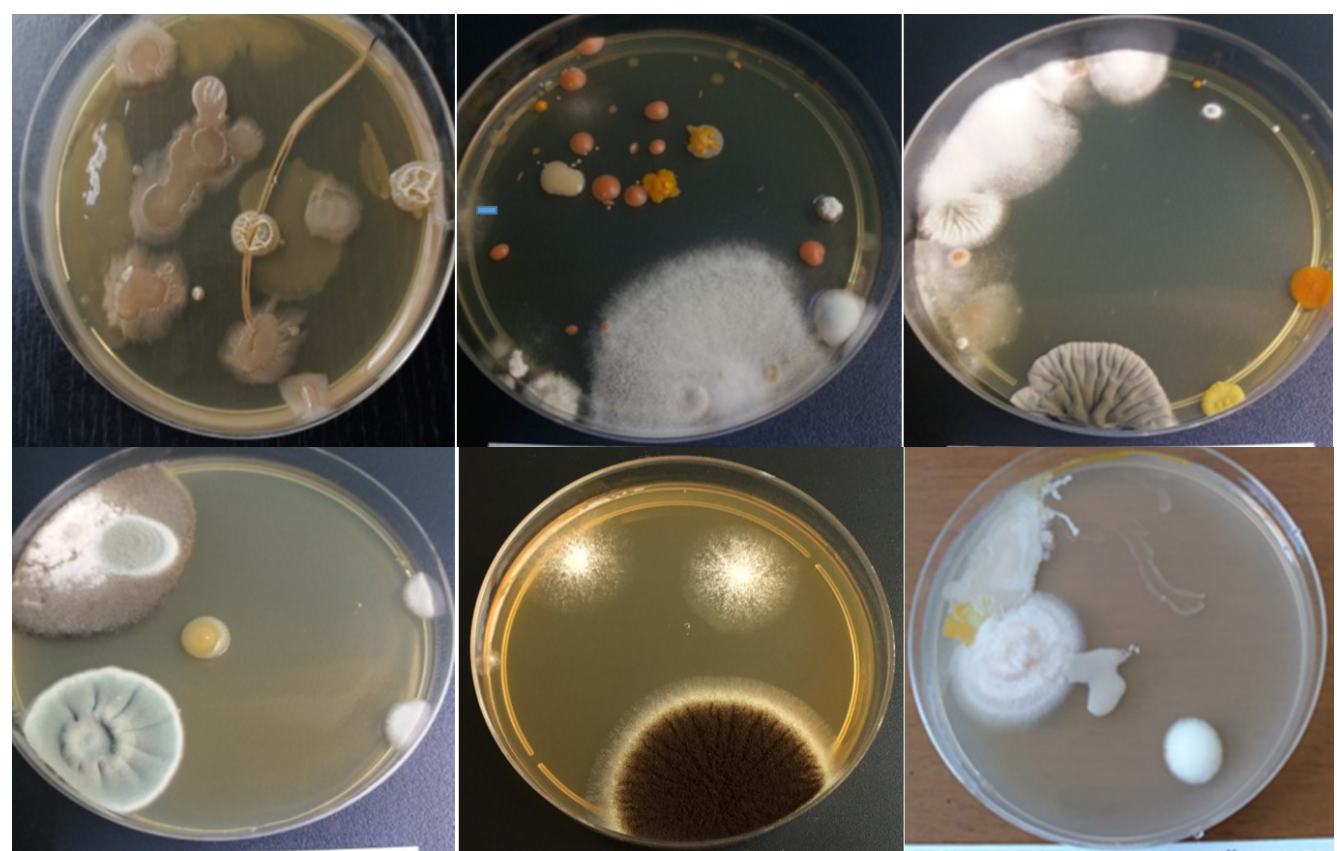

4: Microflora of refrigerator No. 1 for storing cooled beef cuts $\left(t=-4.5^{\circ} \mathrm{C}\right)$

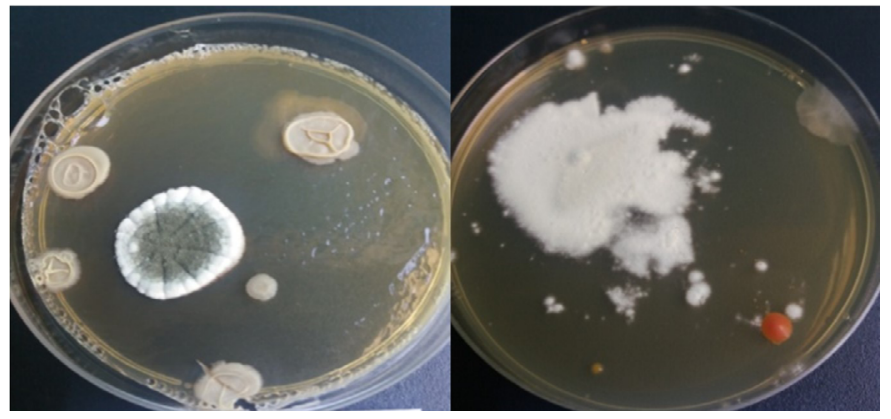

5: Microflora of refrigerator No. 2 for storing meat products (sausages) $\left(t=+4.50^{\circ} \mathrm{C}\right)$

In the air of refrigerator No. 1, a cells of sporeforming mesophilic bacteria Bacillus sp. and Sarcina sp., yeast Rhodotorula sp., and mycelial fungus Penicillium sp., Alternaria sp., Mucor sp., Aspergillus sp. and a single colony of the psychrophilic fungus Tamnidium sp. were detected (Fig. 4).

- In the refrigerator No. 2, designed for storing meat products (sausages) - in the washouts, a cells of spore-forming bacteria Bacillus subtilis and Bacillus mesentericus, and fungus Penicillium $s p$. were detected.

In the air of refrigerator No. 2, a cells of yeast Rhodotorula sp., spore-forming bacteria Bacillus subtilis and mycelial fungi Penicillium sp., Mucor sp. and Chrososporum sp. were detected (Fig. 5).

The method of metagenomic analysis is designed to determine cultivated, persistent and uncultivated microflora and can be used to analyze the sanitary condition of air and refrigeration equipment of meat processing enterprises and to detect pathogens of food poisoning in production.
The results of metagenomic sequencing of samples of washouts from the walls and shelves of refrigerating chambers are presented in Fig. 6.

The bacterial composition of the surfaces of the refrigerator for cooled meat is mainly represented by Phyla: Firmicutes (95.33\%), Proteobacteria (1.39\%), Actinobacteria (1.11\%) and others (Fig. 6). According to the results of metagenomic analysis of the bacterial microflora of refrigerating chambers, it can be concluded that the most significant number of bacteria in the refrigerator for cooled meat $\left(\mathrm{t}=-4.5^{\circ} \mathrm{C}\right)$ belong to the genera: Bacillus $86.46 \%$, Paenibacillus - 1.9\%, Brevibacillus - 1.63\%, Staphylococcus $-1.09 \%$, Terribacillus $-0.73 \%$, etc. In sanitary terms, the following microorganisms deserve attention: Staphylococcus sp. (1.09\%), Bacillus oleronius (11.42\%), Bacillus cereus (0.84\%) - pathogens of food toxicoinfections, skin infections, etc.

The bacteria of the refrigerating chamber No. 2 for meat products, in general, belong to the phylum Firmicutes (97.94\%) and only a small number of identified bacteria are representatives of the phyla 


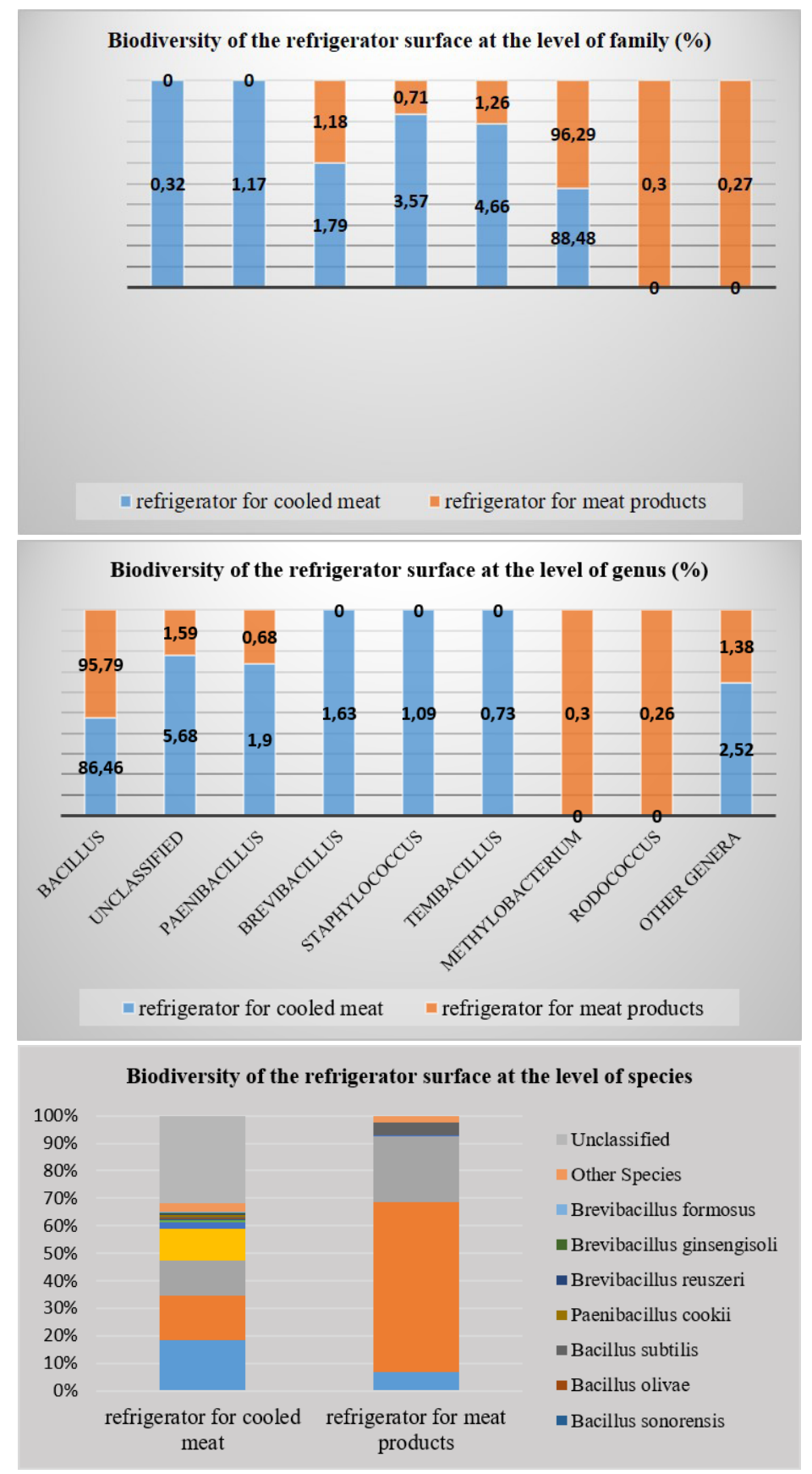

6: Identification of the complete bacterial composition of the microflora of refrigerators for cooled meat $\left(t=-4.5^{\circ} \mathrm{C}\right)$ and meat products $\left(t=+4.5^{\circ} \mathrm{C}\right)$ by metagenomic analysis

Proteobacteria (1.02\%), Actinobacteria (0.63\%) and others (Fig. 3). In the microflora of the refrigerator for finished meat products $\left(\mathrm{t}=+4.5^{\circ} \mathrm{C}\right)$, genera are represented: Bacillus - 95.79\%, Paenibacillus - 0.68\%, Methylobacterium - 0.3\%, Rhodococcus $0.26 \%$ and others.

The quality of meat and meat products during storage depends not only on the sanitary and hygienic conditions of refrigeration processing, but also on the degree of its initial microbiological contamination. Microbiological indicators can be to some extent an objective indicator of the degree of freshness and safety of meat and meat products. In this regard, to study the influence of the sanitary condition of refrigeration equipment on the quality of meat and meat products, we, in parallel with the selection of washouts from refrigeration equipment and analysis of the air of the chambers, samples of beef meat in cuts and meat products were taken before laying for storage ( 0 days - checking for initial contamination by microorganisms), as well as during 3 and 7 days of storage. 
III: Sanitary condition of meat stored in refrigerating chamber No. 1 at $-4.5^{\circ} \mathrm{C}$

\begin{tabular}{|c|c|c|c|c|c|}
\hline \multirow[b]{2}{*}{ Object of study } & \multirow[b]{2}{*}{ Shelf life } & \multicolumn{4}{|c|}{ Microbiological indicators of meat quality, CFU/g } \\
\hline & & QMAFAnM, CFU/g & $\begin{array}{l}\text { CGB (coliforms), } \\
\text { in } 0.001 \mathrm{~g}\end{array}$ & $\begin{array}{l}\text { Pathogenic, including } \\
\text { Salmonella sp., in } 25 \mathrm{~g}\end{array}$ & $\begin{array}{l}\text { L. monocytogenes, } \\
\text { in } 25 \mathrm{~g}\end{array}$ \\
\hline \multirow{2}{*}{$\begin{array}{l}\text { Part of the cut } \\
\text { "meat beef hip" } \\
\text { (81 samples) }\end{array}$} & 0 days & $(5.0 \pm 0.02) \times 10^{4}$ & Not detected & Not detected & Not detected \\
\hline & 3 days & $(5.2 \pm 0.02) \times 10^{4}$ & Not detected & Not detected & Not detected \\
\hline \multirow{3}{*}{$\begin{array}{l}\text { Part of the } \\
\text { cut "meat } \\
\text { beef brisket" } \\
\text { (81 samples) }\end{array}$} & 0 days & $(5.4 \pm 0.08) \times 10^{5}$ & Detected & Not detected & Not detected \\
\hline & 3 days & $(5.5 \pm 0.06) \times 10^{5}$ & Detected & Not detected & Not detected \\
\hline & 7 days & $(4.8 \pm 0.03) \times 10^{5}$ & Detected & Not detected & Not detected \\
\hline
\end{tabular}

IV: Sanitary condition of meat products stored in refrigerating chamber No. 2 at $+4.5^{\circ} \mathrm{C}(\mathrm{N} / \mathrm{D}$-not detected)

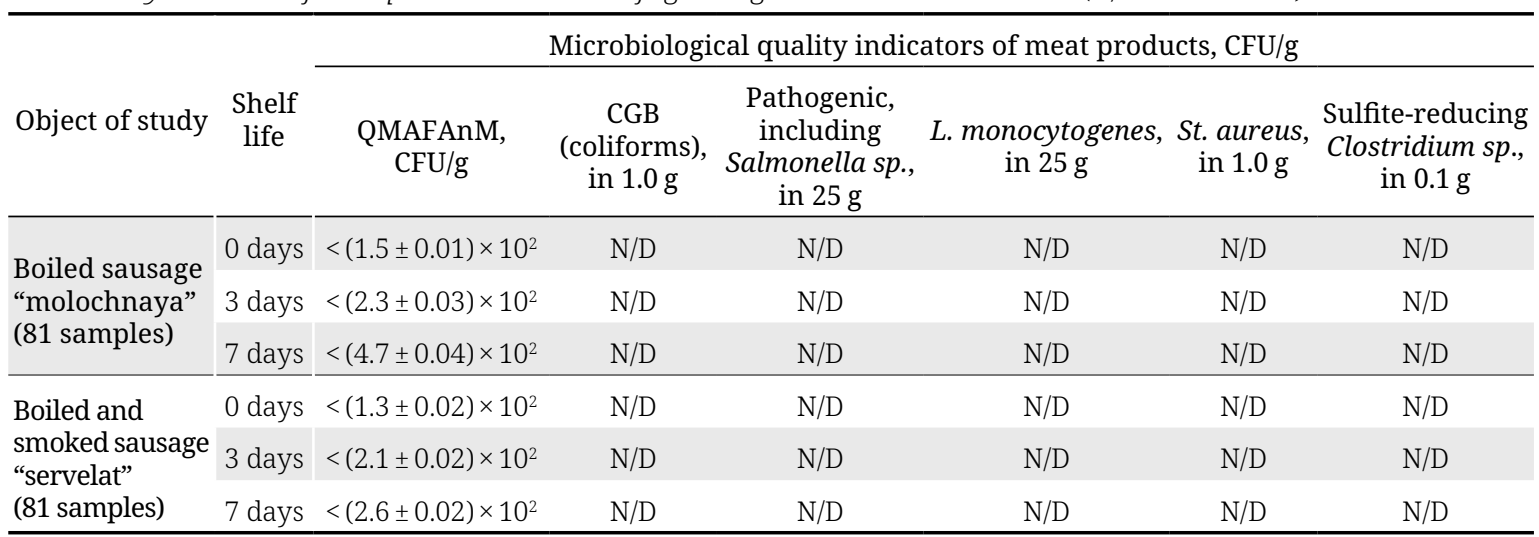

The analysis of meat and meat products was carried out in the accredited testing laboratory "Nutritest", Almaty.

The results of the microbiological study of the sanitary condition of cooled meat are presented in Tab. III.

As shown by the results presented in Tab. III, from two types of samples of meat laid in the refrigerator No. $1\left(t=-4.5^{\circ} \mathrm{C}\right)$ for storage in a cooled form, samples part of the cut "meat beef hip" was fresh and safe in accordance with the requirements of TR CU 034/2013. Samples part of the cut "beef brisket meat" according to the indicators of QMAFAnM could be classified as conditionally fresh meat, but coliforms from CGB group were found in these samples, which did not meet the safety requirements of TR CU 034/2013.

During storage in a cooled state, both meat samples showed a slight reduction in the number of microorganisms. On the third day of cooling, the development of mesophilic microorganisms on the surface of the meat slowed down and stopped their reproduction. With further storage of chilled meat samples for up to 7 days, the QMAFAnM index decreased slightly, due to the death of the sporeless microflora. The bacteria of the Escherichia coli group found in samples "part of the cut "meat beef brisket" did not die during cooling at $-2{ }^{\circ} \mathrm{C}$. $E$. coli bacteria, as a rule, do not cause spoilage of meat, but are only an indicator of the sanitary and hygienic level of production, however, according to modern data from FAO and WHO, they can cause food poisoning in certain conditions.

The presence in meat samples of such a high initial number of mesophilic microorganisms, especially spores, as well as the detection of bacteria Escherichia coli group in some of them indicates insufficient compliance with sanitary and hygienic rules in technological premises at the meat processing plant, where meat is contaminated during slaughter and processing of carcasses, even before being placed in refrigerators.

The results of the microbiological study of the sanitary condition of meat products (sausages) in the process of cold storage are presented in Tab. IV.

As shown by the results presented in Tab. IV, of the two types of samples of meat products stored in refrigerator No. $2\left(\mathrm{t}=+4.5^{\circ} \mathrm{C}\right)$ for storage in a cooled form, both samples of sausages (boiled sausage "molochnaya", boiled-smoked sausage "servelat") were fresh and safe in accordance with the requirements of TR CU 034/2013.

\section{DISCUSSION}

It should be noted that after washing and disinfection, we did not observe any traces of visible contamination on the surface of the test objects. At the same time, when conducting tests for the quality of sanitary measures (the number 
of microorganisms), we found the presence of single cells of bacteria, yeast and mold fungi on the studied surfaces of the shelves. Meat fragments could remain on the shelves, which, after their own enzymes exposure, serve as an excellent nutrient substrate for mesophilic microorganisms (Drosinos and Board, 1994; Brown et al., 2014), and also initiates biofilm formation (Li et al., 2017; Wang et al., 2015; Xianqin et al., 2018; Wang et al., 2017; Ferreira et al., 2015; Lebeaux and Ghigo, 2012).

During 7 days of storage of meat and meat products(sausages) in both refrigerators, single cells of bacteria and yeast on the shelves significantly multiplied. According to the current rules, the quality of the washing process was evaluated as "clean". But, as already mentioned above, the presence of residual microflora can lead to the formation of biofilms and subsequent spoilage of meat products. Microbial cells that produce exopolysaccharides, without timely and complete removal from the surfaces of technological equipment, quickly form a biofilm. Such microbial communities are found both with the use of classical microbiological analysis and with the use of metagenomic analysis, for example, on the surfaces of shelves, where bacteria hold firm, resisting removal, washing and the action of conventional disinfectants that cannot penetrate the polysaccharide membrane of the cell walls of bacteria. All this leads, ultimately, not only to contamination of the final meat products, but also causes biocorrosion of equipment. Therefore, it is so important to control the cleanliness of various surfaces of the technological process in the meat industry.

Metagenomic analysis revealed some types of bacteria that in the classical study of the sanitary condition of refrigerating chambers were not determined. Most bacteria are spore based, which allows them to survive in adverse conditions. However, it should be noted, that most of the atypical microorganisms for the meat microflora detected by metagenomic analysis belong to soil microorganisms and could be entered into the chambers by employees of enterprises that do not comply with sanitary and hygienic standards.

Of these, the bacteria from the surfaces of the refrigerating chamber for cooled meat Paenibacillus cookie $(0.72 \%)$ (the first strain was isolated from the soils of Antarctica) (Logan et al., 2004) and Bacillus sonorensis sp (0.59\%), which produces hydrogen cyanide are most interesting (Palmisano et al., 2001). Both of these microorganisms are prone to biofilm formation.

Of the bacteria found by metagenomic analysis in the chambers for storing meat products deserve attention: Rhodococcus sp. (0.26\%) - some species may be pathogenic (Makrai et al., 2008); Bacillus axarquiensis (45.86\%), Bacillus malacitensis (5.29\%), - halotolerant species (Dunlap et al., 2016); Bacillus mucilaginosus (18.77) is a producer of exopolysaccharides, viable during prolonged exposure to liquid nitrogen $\left(-196^{\circ} \mathrm{C}\right)$ and when heated to $160^{\circ} \mathrm{C}$ (Pestova, 2000); Bacillus horneckiae (0.39\%) - spores are resistant to UV radiation up to 1000 J m (-2) (Vaishampayan et al., 2004).

The safety and quality of meat and meat products, as well as its shelf life, are influenced by various factors, among which the predominant role belongs to microbiological ones, since the appearance and development of undesirable changes in products, including the danger to the health of consumers, depend on them in the vast majority. In addition to meat and meat products, the following representatives of the microflora can be considered the main cause of foodborne diseases: Salmonella sp., L. monocytogenes, E. coli, B. cereus, Clostridium perfringens, Campilobacter jejuni, Yersinia enterocolitica, E. faecium, E. faecalis. This also applies to the toxins of $S$. aureus and $C$. botulinum.

Enterotoxicosis, the cause of which is primarily the enterotoxin Staphylococcus aureus, is observed in people when consuming food, including meat products. Coagulase-positive staphylacocci (S. aureus, S. intermedius, S. nyicus) are considered pathogenic for humans. Among them, $S$. aureus is most often reacted in animals, as well as in raw meat and products made from it. Along with coagulase activity, it has the ability to toxin formation.

The quality of meat and products made from is affected by bacilli and bacteria that secrete proteolytic enzymes, as well as microscopic fungi, yeast. Cooled and frozen meat raw materials (meat in carcasses, half-carcasses, quarters and cuts, meat in blocks, poultry meat, mechanically deboned meat, byproducts), semi-finished products, as well as raw smoked (dried) products are classified as high risk of contamination by bacteria Salmonella sp., L. monocytogenes. The frequency of detection of bacteria Listeria $s p$. indicates an intensive circulation of the causative agent of listeriosis in meat processing enterprises.

Of all these groups of microorganisms, only the microorganisms of the CGB (coliforms) in some meat samples under study were found in the experiments. The remaining samples of meat and meat products were fresh and safe in accordance with the requirements of TR TS 034/2013.

If on results of the studies you evaluate the influence of the sanitary condition of refrigeration equipment for periods of storage of cooled meat and meat products, it should be noted that among the species composition of microflora in meat samples stored in the refrigerator, not detected toxigenic bacteria St. aureus, B. cereus, mesophilic yeast and mold, and psychrophilic fungi Alternaria sp. and Cladosprium sp. that were discovered on the surfaces and in the air cooling chambers in a single amount. This is confirmed by the analysis data of the accredited testing laboratory of "Nutritest" LLP. The study of a sample of beef meat for the 
total microbial number revealed the presence of a significant number gram-positive cells lactic acid bacteria, spore-forming bacteria Bacillus subtilis and gram-negative Pseudomonas sp.

Such, in the course of the conducted research, it is shown that at meat processing enterprises of the Almaty region, the sanitary condition of refrigerating chambers meets the safety requirements and does not have a negative impact on the quality and shelf life of meat and meat products. All the meat put into storage was fresh and safe. Clean chamber, in combination with the optimal technological regime of cooling (humidity and speed of air supply) they contribute to maintaining the level of microbial contamination of meat laid for cold storage (CFU) within the same order and maintaining the corresponding storage periods of meat and meat products. It should be noted that to ensure greater safety of the refrigeration process, employees of the enterprise must strictly comply with sanitary and hygienic standards and rules of operation in refrigerating chambers and other technological premises of the meat processing enterprise.

\section{CONCLUSION}

Sanitary assessment of the refrigerating chambers of meat processing plants of Almaty region (south-east of Kazakhstan) by the degree of their microbiological contamination showed that the total microbial contamination of the walls, technological equipment and air of the refrigerating chambers within 7 days after disinfection and loading of meat and meat products for storage was quite low, and depended on two main factors - the temperature in the refrigerating chamber and the duration of storage of products.

Microflora of refrigerating compartment surfaces is more represented by the spores bacterial microflora - Bacillus sp., Pseudomonas sp., Sarcina flava, Paenibacillus sp., Rodococcus sp. and others, including those not specific to meat (probably microorganisms brought from the outside with meat baskets, clothing and staff shoes), as confirmed by the results of metagenomic studies. To a lesser extent, yeast Rhodotorula sp., mycelial fungi Penicillium sp., Alternaria sp., Mucor sp., Aspergillus sp., Chrososporum $s p$.

In the air of refrigerating chambers, cells of fungi Penicillium sp., Aspergillus sp., Mucor sp., Chrososporum sp. and yeast Rhodotorula sp., but there are also single cells of the psychophilic fungi Tamnidium and Alternaria, which, when propagated, can cause spoilage of meat and meat products. Bacterial microflora is mainly by bacteria Bacillus sp., less commonly Sarcina flava represented.

A study of the level of microbial contamination of meat and meat products laid for cold storage for 7 days showed a slight increase in the number of microorganisms within one order. Meat and meat products were fresh and safe. The established level of microbial contamination of refrigerating chambers did not negatively affect the quality and shelf life of meat and meat products.

Microbiological and metagenomic studies of the sanitary condition of refrigeration equipment made it possible to establish two critical points of control of refrigeration equipment, threatening the safety of meat and meat products. One of the critical control points is the surface of shelves, boxes for storing byproducts, hanging hooks in refrigerating chambers. This production equipment should be washed and disinfected with greater caution, since it has been found to contain the largest number of microorganisms that have survived after the general disinfection of the chambers. The second critical control point is the accounting and control of personnel movement during the preparation of the sanitary plan of the enterprise (the presence of assigned departments and the timely change of personal clothes and shoes, a pass system, an automatic foam sprayer with disinfectant at the places of transition of personnel, carts, loaders and others in the area of storage of meat and meat products in the refrigerator). To prevent the introduction of microorganisms from the external environment and ensure greater safety of the refrigeration process, employees of the enterprise must strictly comply with sanitary and hygienic standards and rules of operation in refrigerating chambers and other technological premises of the meat processing plant.

The research results can serve as the basis for recommendations for improving the sanitary condition and safety at meat processing plants.

\section{Acknowledgements}

The materials were prepared as part of the implementation of the event "Study of the impact of sanitary conditions, refrigeration equipment on the shelf life of meat and meat products". Development of recommendations on the project "Processing of cattle meat" within the framework of the scientific and technical program No. BR06249209 "Development of intensive technologies in livestock industries" of the budget program 267 "Increasing the availability of knowledge and scientific research" subprogram 101 "Program-targeted financing of scientific research and activities" of the Ministry of Agriculture of the Republic of Kazakhstan for 2018-2020. 


\section{REFERENCES}

BAI, A. J. and RAI VITTAL, R. 2014. Quorum sensing regulation and inhibition of exoenzyme production and biofilm formation in the food spoilage bacteria Pseudomonas psychrophila PSPF19. Food Biotechnology, 28(4): 293-308.

BROOKS, J. D. and FLINT, S. H. 2008. Biofilms in the food industry: problems and potential solutions. International Journal of Food Science \& Technology, 43(12): 2163-2176.

BROWN, H. L., REUTER, M., SALT, L. J., CROSS, K. L., BETTS, R. P. and VAN VLIET, A. H. M. 2014. Chicken juice enhances surface attachment and biofilm formation of Campylobacter jejuni. Applied and Environmental Microbiology, 80(22): 7053-7060.

COOMBS, C. E. O., HOLMAN, B. W. B., FRIEND, M. A. and HOPKINS, D. L. 2017. Long-term red meat preservation using chilled and frozen storage combinations: A review. Meat Science, 125: 84-94.

DELHALlE, L., TAMINIAU, B., FASTREZ, S., FALL, A., BALLESTEROS, M., BURTEAU, S. and DAUBE, G. 2020. Evaluation of Enzymatic Cleaning on Food Processing Installations and Food Products Bacterial Microflora. Frontiers in Microbiology, 11: 1827.

DOSPEKHOV, B. A. 2012. Methodology of field experience (with the basics of statistical processing of research results) [in Russian: Методика полевого опыта (с основами статистической обработки результатов исследований)]. Moscow: Book on Demand.

DOULGERAKI, A. I., ERCOLINI, D., VILLANI, F. and NYCHAS, G. J. E. 2012. Spoilage microbiota associated to the storage of raw meat in different conditions. International Journal of Food Microbiology, 157(2): 130-141.

DROSINOS, E. H. and BOARD, R. G. 1994. Growth of Listeria monocytogenes in meat juice under a modifi ed atmosphere at $4^{\circ} \mathrm{C}$ with or without members of a microbial association from chilled lamb under a modified atmosphere. Letters in Applied Microbiology, 19(3): 134-137.

DUNLAP, C. A., BOWMAN, M. J., SCHISLER, D. A. and ROONEY, A. P. 2016. Genome analysis shows Bacillus axarquiensis is not a later heterotypic synonym of Bacillus mojavensis; reclassification of Bacillus malacitensis and Brevibacterium halotolerans as heterotypic synonyms of Bacillus axarquiensis. International Journal of Systematic and Evolutionary Microbiology, 66(6): 2438-2443.

ERCOLINI, D., RUSSO, F., TORRIERI, E., MASI, P. and VILLANI, F. 2006. Changes in the spoilage-related microbiota of beef during refrigerated storage under different packaging conditions. Applied and Environmental Microbiology, 72(7): 4663-4671.

FAO. 2019. Regional Overview of Food Security and Nutrition in Europe and Central Asia 2019. Structural Transformations of Agriculture for Improved Food Security, Nutrition and Environment. Budapest: FAO.

FERREIRA, S., FRAQUEZA, M. J., QUEIROZ, J. A., DOMINGUES, F. C. and OLEASTRO, M. 2015. Genetic diversity, antibiotic resistance and biofilm-forming ability of Arcobacter butzleri isolated from poultry and environment from a Portuguese slaughterhouse. International Journal of Food Microbiology, 162(1): 82-88.

KLINDWORTH, A., PRUESSE, E., SCHWEER, T., PEPLIES, J., QUAST, C. et al. 2013. Evalution of general 16S ribosomal RNA gene PCR primers for classical and next-generation sequencing-based diversity studies. Nucleic acids research, 41(1): e1.

KOSTENKO, Y. G. 2015. Guidelines for sanitary and microbiological bases and prevention of risks in the production and storage of meat products [in Russian: Руководство по санитарноймикробиологическим основам и предупреждению рисков при производстве и хранении мясной продукции]. Moscow: Technosphere.

KRIEG, N. R. et al. (Eds.). 2010. Bergey's Manual of Systematic Bacteriology. Vol. 4: The Bacteroidetes, Spirochaetes, Tenericutes (Mollicutes), Acidobacteria, Fibrobacteres, Fusobacteria, Dictyoglomi, Gemmatimonadetes, Lentisphaerae, Verrucomicrobia, Chlamydiae, and Planctomycetes. $2^{\text {nd }}$ Edition. New York: Springer.

LEBEAUX, D. and GHIGO, J. M. 2012. Management of biofilm-associated infections: what can we expect from recent research on biofilm lifestyles? Médecine sciences, 28(8-9): 727-739.

LEE, K. W. K., PERIASAMY, S., MUKHERJEE, M., XIE, C., KJELLEBERG, S. and RICE, S. A. 2014. Biofilm development and enhanced stress resistance of a model, mixed-species community biofilm. ISME Journal, 8(4): 894-907.

LI, J., FENG, J., MA, L., de la FUENTE NUNEZ, C., GOLZ, G. and LU, X. 2017. Effects of meat juice on biofilm formation of Campylobacter and Salmonella. International Journal of Food Microbiology, 253: 20-28.

LIU, X., JI, L., WANG, X., LI, J., ZHU, J. and SUN, A. 2018. Role of RpoS in stress resistance, quorum sensing and spoilage potential of Pseudomonas fluorescens. International Journal of Food Microbiology, 270: 31-38.

LIU, Y. J., XIE, J., ZHAO, L. J., QIAN, Y. F., ZHAO, Y. and LIU, X. 2015. Biofilm formation characteristics of Pseudomonas lundensis isolated from meat. Journal of Food Science, 80(12): 2904-2910. 
LOGAN, N. A., DE CLERCK, E., LEBBE, L., VERHELST, A., GORIS, J., FORSYTH, G., RODRIGUEZ-DIAZ, M., HEYNDRICKX, M. and DE VOS, P. 2004. Paenibacillus cineris sp. nov. and Paenibacillus cookii sp. nov., from Antarctic volcanic soils and a gelatin-processing plant. International Journal of Systematic and Evolutionary Microbiology, 54(4): 1071-1076.

MAKRAI, L., KOBAYASHI, A., MATSUOKA, M., SASAKI, Y., KAKUDA, T., DÉNES, B., HAJTÓS, I., RÉVÉSZ, I., JÁNOSI, K., FODOR, L., VARGA, J. and TAKAI, S. 2008. Isolation and characterisation of Rhodococcus equi from submaxillary lymph nodes of wild boars (Sus scrofa). Veterinary Microbiology, 131(3-4): 318-323.

MEI, Y.-Z., HUANG, P.-W., LIU, Y., HE, W., FANG, W.-W. 2016. Cold stress promoting a psychrotolerant bacterium Pseudomonas fragi P121 producing trehaloase. World Journal of Microbiology and Biotechnology, 32(8): 1-9.

MOHAREB, F., IRIONDO, M., DOULGERAKI, A. I., Van HOEK, A., AARTS, H., CAUCHI, M., NYCHAS, G.-J. E. 2015. Identification of meat spoilage gene biomarkers in Pseudomonas putida using gene profiling. Food Control, 57(C): 152-160.

NIEMineN, T. T., KOSKINEN, K., LAINE, P., HUlTMAN, J., SADE, E., PAUlin, L., PALORANTA, A., JOHANSSON, P., BJÖRKROTH, J., AUVINEN, P. 2012. Comparison of microbial communities in marinated and unmarinated broiler meat by metagenomics. International Journal of Food Microbiology, 157: 142-149.

NIEMinEN, T. T., VAliTALO, H., SADE, E., PALORANTA, A., KOSKINEN, K., BJÖRKROTH, J. 2012. The effect of marination on lactic acid bacteria communities in raw broiler fillet strips. Frontiers in Microbiology, 3: 376.

OECD. 2020. Meat consumption (indicator). OECDiLibrary. [Online]. Available at: https://doi. org/10.1787/fa290fd0-en [Accessed: 2020, October 15].

OECD/FAO. 2020. OECD-FAO Agricultural Outlook, OECD Agriculture statistics (database). OECDiLibrary. [Online]. Available at: http://dx.doi.org/10.1787/agr-outl-data-en [Accessed: 2020, October 15].

OLUSEGUN, A. O. and INIOBONG, G. N. 2011. Spoilage and preservation of meat: a general appraisal and potential of lactic acid bacteria as biological preservatives. International Research Journal of Biotechnology, 2: 33-46.

PAL, M., AYELE, Y., PATEL, A. S. and DULO, F. 2018. Microbiological and hygienic quality of Meat and Meat Products. Beverage \& Food World, 45(5): 21-27.

PALMISANO, M. M., NAKAMURA, L. K., DUNCAN, K. E., ISTOCK, C. A. and COHAN, F. M. 2001. Bacillus sonorensis sp. nov., a close relative of Bacillus licheniformis, isolated from soil in the Sonoran Desert, Arizona. International Journal of Systematic and Evolutionary Microbiology, 51(Pt5): 1671-1679.

PENNACCHIA, C., ERCOLINI, D. and VILLANI, F. 2011. Spoilage-related microbiota associated with chilled beef stored in air or vacuum pack. Food Microbiology, 28(1): 84-93.

PESTOVA, O. V. 2000. Biosynthesis of exopolysaccharides by Bacillus mucilaginosus bacteria under deep cultivation conditions and a new aspect of their use [in Russian: Биосинтез экзополисахаридов бактериями Бациллус мучилагиносус в глубинных условиях культивирования и новый аспект их использования]. PhD Thesis. St. Petersburg.

ROUGER, A., REMENANT, B., PRÉVOST, H. and ZAGOREC, M. 2017. A method to isolate bacterial communities and characterize ecosystems from food products: Validation and utilization as a reproducible chicken meat model. International Journal of Food Microbiology, 247: 38-47.

ROUGER, A., TRESSE, O. and ZAGOREC, M. 2017. Bacterial Contaminants of Poultry Meat: Sources, Species, and Dynamics. Microorganisms, 5(3): 50.

SAUTER, E. A. 1987. Microbiology of frozen poultry products. In: CUNNINGHAM, F. E. and COX, N. A. (Eds.). The Microbiology of Poultry Meat Products. Academic Press: New York, pp. 333-339.

SOKOLOV, D. M. and SOKOLOV, M. S. 2015. Rapid tests of Singlepath and Duopath for detection of pathogenic microorganisms and toxins in food products [in Russian: Экспресс-mесты Singlepath u Duораth для выявления патогенных микроорганизмов и токсинов в пищевых продуктах]. Dairy industry, 1: 4-6.

STANBOROUGH, T., FEGAN, N., POWELL, S. M., SINGH, T., TAMPLIN, M. and CHANDRY, P. S. 2018. Genomic and metabolic characterization of spoilage-associated Pseudomonas species. International Journal of Food Microbiology, 268: 61-72.

STELLATO, G., LA STORIA, A., De FILIPPIS, F., BORRIELLO, G., VILLANI, F. and ERCOLINIA, D. 2016. Overlap of Spoilage-Associated Microbiota between Meat and the Meat Processing Environment in Small-Scale and Large-Scale Retail Distributions. Applied and Environmental Microbiology, 82(13): 4045-4054.

THE GREENGENES DATABASE. 2020. The Green Genes. [Online]. Available at:_https://greengenes.lbl. gov/Download/FAQS/index.htm [Accessed: 2020, October 15]. 
TULYAKOVA, T. V., FURSOVA, I. A. and SHIBANOV, E. I. 2013. Safety of food raw materials - the most important component of food safety [in Russian: Безопасность продовольственного сырья важнейшая составляющая безопасности пищевых продуктов]. Food industry, 5: 33.

UK STATUTORY INSTRUMENTS. 2002. The Meat (Hazard Analysis and Critical Control Point) (England). Statutory Instrument No. 889. UK Statutory Instruments.

VAISHAMPAYAN, P., PROBST, A., KRISHNAMURTHI, S., GHOSH, S., OSMAN, S., MCDOWALL, A., RUCKMANI, A., MAYILRAJ, S. and VENKATESWARAN, K. 2004. Bacillus horneckiae sp. nov., isolated from a spacecraft-assembly clean room. International Journal of Systematic and Evolutionary Microbiology, 60(5): 1031-1037.

VOS, P., GARRITY, G., JONES, D., KRIEG, N. R., LUDWIG, W., RAINEY, F. A., SCHLEIFER, K.-H. and WHITMAN, W. (Eds.). 2009. Bergey's Manual of Systematic Bacteriology. Vol. 3: The Firmicutes. $2^{\text {nd }}$ Edition. New York: Springer.

WANG, H., QI, J., DONG, Y., LI, Y., XU, X. and ZHOU, G. 2017. Characterization of attachment and biofilm formation by meat-borne Enterobacteriaceae strains associated with spoilage. LWT - Food Science and Technology, 86: 399-407.

WANG, H., ZHANG, X., ZHANG, Q., XINGLIAN, K. Y. and ZHOU, X. G. 2015. Comparison of microbial transfer rates from Salmonella spp. biofilm growth on stainless steel to selected processed and raw meat. Food Control, 50: 574-580.

WHITMAN, W. et al. (Eds.). 2012. Bergey's Manual of Systematic Bacteriology. Vol. 5: The Actinobacteria. $2^{\text {nd }}$ Edition. New York: Springer.

WICKRAMASINGHE, N. N., RAVENSDALE, J., COOREY, R., CHANDRY, S. P. and DYKES, G. A. 2019. The Predominance of Psychrotrophic Pseudomonads on Aerobically Stored Chilled Red Meat. Comprehensive Reviews in Food Science and Food Safety, 18(5): 1622-1635.

XIANQIN, Y., WANG, H., HE, A. and TRAN, F. 2018. Biofilm formation and susceptibility to biocides of recurring and transient Escherichia coli isolated from meat fabrication equipment. Food Control, 90: 205-211. 